\title{
High-throughput sequencing reveals that pale green lethal disorder in apple (Malus) stimulates stress responses and affects senescence
}

\author{
Benjamin Orcheski $^{1}$ (D) Susan Brown ${ }^{1}$ \\ Received: 11 October 2016 /Revised: 13 December 2016/Accepted: 21 December 2016/Published online: 31 December 2016 \\ (C) The Author(s) 2016. This article is published with open access at Springerlink.com
}

\begin{abstract}
Pale green lethal (PGL) is a recessive genetic disorder of apple (Malus) characterized by severe chlorophyll deficiency and seedling lethality. Following germination, seedlings cannot photosynthesize and die at the cotyledon stage. We previously reported that the genetic and biochemical basis of PGL is due to a loss-of-function mutation in a gene required for the biosynthesis of phylloquinone (vitamin $\mathrm{K}_{1}$ ), a molecule essential for photosynthesis. For the present study, we used Illumina high-throughput RNA sequencing to identify genes differentially regulated between wild-type and PGL cotyledons. Changes in the expression of chlorophyll-related genes alone cannot explain the reduced chlorophyll content of PGL seedlings. However, genes putatively responding to numerous stress-related conditions including carbohydrate starvation, water deficit, and senescence were differentially regulated. This pattern of transcript accumulation suggests PGL seedlings alter many physiological and metabolic processes such as sorbitol metabolism, osmoprotectant production, and abscisic acid activity. The functions of individual genes relating to specific stresses are discussed. These findings provide insight into possible mechanisms PGL seedlings employ
\end{abstract}

Communicated by D. Chagné

Electronic supplementary material The online version of this article (doi:10.1007/s11295-016-1097-5) contains supplementary material, which is available to authorized users.

Benjamin Orcheski

bbo5@cornell.edu

Susan Brown

skb3@cornell.edu

1 School of Integrated Plant Science, Section of Horticulture, New York State Agricultural Experiment Station, Cornell University, Geneva, NY 14456, USA during stress response. Pale green lethal disorder may be a useful model for studying abiotic stress and senescence in rosaceous fruit tree species.

Keywords Apple $\cdot$ Malus $\cdot$ Cotyledon - Water deficit Starvation $\cdot$ Senescence

\section{Introduction}

A recessive genetic disorder called pale green lethal (PGL) is located on LG 16 of apple (Malus), in an area with many genes of importance in breeding (Bai et al. 2012; Khan et al. 2012; Buti et al. 2015). The disorder is evident soon after germination since seedlings with PGL have light green cotyledons and leaves (Way et al. 1976). Wild-type (WT) seedlings have several fully developed true leaves, while PGL seedlings produce only two to three stunted leaves (Fig. 1a). PGL seedlings also fail to develop an adequate root system (Fig. 1b). Within a month after germination, the true leaves become necrotic, followed by the cotyledons and seedlings die.

PGL is a frequent problem in apple breeding programs because carriers of the mutant allele are prevalent and include varieties used commonly for breeding, such as 'Golden Delicious,' 'Fuji,' and 'Jonathan.' When two carriers are crossed, $25 \%$ of seedlings are PGL and die, representing a significant loss of time and resources, while biasing observed segregation of important linked traits.

We previously reported that PGL is caused by a loss-offunction mutation in MdPHYLLO, encoding an enzyme required to produce phylloquinone (vitamin $\mathrm{K}_{1}$ ), a molecule essential for photosynthesis (Orcheski et al. 2015). Pale green lethal seedlings do not produce phylloquinone and cannot photosynthesize, causing severe carbohydrate starvation 


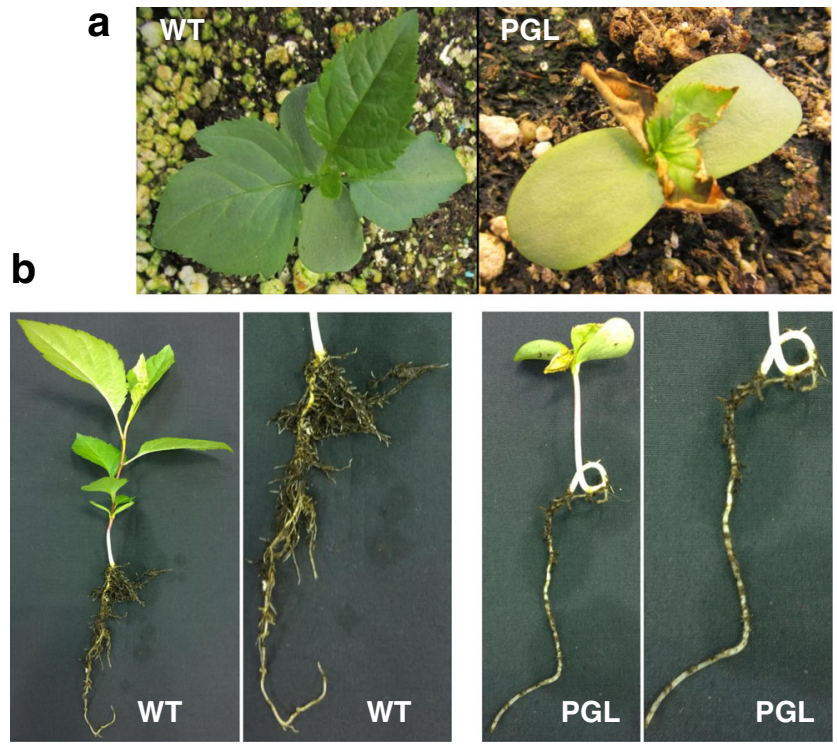

Fig. 1 Wild-type and pale green lethal seedlings. a Leaves and cotyledons of 3-week-old seedlings. b Root structure of 3-week-old seedlings. Wild-type seedlings have a well-developed root structure, while pale green lethal seedlings have only a taproot with little fibrous root development

stress. Furthermore, poor root development in PGL seedlings likely impairs their ability to transport water adequately, leading to water deficit stress. Several mutants in the phylloquinone biosynthesis pathway have been isolated from Arabidopsis (Shimada et al. 2005; Gross et al. 2006; Kim et al. 2008) and display similar phenotypes to PGL, including reduced chlorophyll content and early seedling death. However, no study has yet determined the impact that a mutation in the phylloquinone pathway has on gene expression. Our goal was to determine how gene expression is altered by PGL disorder and infer the physiological and metabolic mechanisms used to respond to stress caused by the mutated MdPHYLLO gene.

High-throughput sequencing of RNA (RNA-seq) is a useful tool to study a mutant phenotype, even in non-model species (de Heredia and Vázquez-Poletti 2016). While RNA-seq cannot determine how physiological and metabolic processes are affected by a mutation, it provides a framework and starting point to build testable models for further research. We used RNA-seq to compare transcriptomes of wild-type and pale green lethal cotyledons. Cotyledons were used as the RNA source because they display the PGL phenotype and are the most abundant tissue available. The two cotyledons on an apple seedling are at a similar developmental stage, making them sound biological replicates.

Illumina sequencing of cotyledon RNA detected the expression of almost 22,000 genes, with over 3700 displaying differential accumulation of transcripts (those with a $P$ value $<9.9 \mathrm{E}^{-5}$ ). From these 3700 , the 200 genes with a false discovery rate (FDR, $Q$ value) of $9.9 \mathrm{E}^{-35}$ or less were analyzed in detail. Analysis of these genes helped to elucidate the stress response of PGL seedlings. Regarding starvation and water deficit stresses, genes appear to be regulated in order to alter basic carbohydrate metabolism and acclimate the plant to water deficit. Carbohydrate starvation and water deficit stress are known to stimulate organ senescence to reallocate energy and limit water loss through transpiration, respectively (Schippers et al. 2015; Basu et al. 2016). In PGL seedlings, however, numerous genes putatively involved in the initiation and progression of senescence were downregulated, indicating developmentally programmed senescence is slowed. Many gene regulation changes involved conserved responses employed by other plants during stress conditions, such as the production of osmoprotectant proteins and small molecules during water deficit stress (Mishra et al. 2016). RNA-seq data suggests that some responses to the stress imposed by PGL may be unique to apple, such as altered expression of sorbitol metabolism genes.

We propose that as the primary photosynthesizing organ of young seedlings, PGL plants try to maintain cotyledon integrity so they can recover from carbohydrate deprivation, despite the mutant MdPHYLLO allele preventing photosynthesis. RNA-seq data suggests seedlings change their physiology and development to ensure cotyledons have an ample supply of carbohydrate, do not have water deficit stress, and do not undergo the normal senescence program. The conclusions of this transcriptomics study provide a starting point to further understand PGL disorder with physiological and metabolomics experiments.

Our findings increase understanding of pale green lethal disorder and provide insight into how these plants manage a lethal mutation that imposes numerous stresses. By determining changes in the expression of stress-related genes, this study may provide practical targets for increasing stress tolerance in rosaceous fruit tree species. PGL disorder may also be a useful model to study diverse processes such as carbohydrate metabolism, water transport, and senescence.

\section{Results}

\section{Illumina sequencing of cotyledon RNA}

To prepare PGL biological replicate sequencing libraries, cotyledons from six seedlings were excised and six cotyledons were used to create two pools for RNA isolation (Supplementary material; Fig. S1). This was repeated for WT. Libraries were single-end sequenced on the Illumina HiSeq2000 platform for 101 cycles, with $4 \mathrm{X}$-multiplex, to generate 130,079,044 raw reads. The four libraries produced varying numbers of reads, from 24.7 million (PGL replicate 1) to 39.9 million (WT replicate 2) (Table 1). Only $3 \%$ to $4 \%$ of raw reads were removed from the libraries due to quality issues such as low read length or quality score. Unambiguous reads 
Table 1 RNA-seq read statistics from the four pale green lethal and wild-type cotyledon sample sequencing libraries

\begin{tabular}{|c|c|c|c|c|c|}
\hline Library & Raw reads & $\begin{array}{l}\text { Clean } \\
\text { reads }(\mathrm{Q} \\
30 \mathrm{~L} \mathrm{50)}\end{array}$ & $\begin{array}{l}\text { Reads } \\
\text { mapped to } \\
\text { apple } \\
\text { Genome } \\
\text { v1.0 }\end{array}$ & $\begin{array}{l}\text { Mapping } \\
\text { percentage }\end{array}$ & $\begin{array}{l}\text { Percentage } \\
\text { of reads } \\
\text { aligning to } \\
\text { a single } \\
\text { locus }\end{array}$ \\
\hline $\begin{array}{l}\text { PGL } \\
\text { Rep. } \\
1\end{array}$ & $33,456,853$ & $32,142,998$ & $28,195,651$ & $87.7 \%$ & $30.3 \%$ \\
\hline $\begin{array}{l}\text { PGL } \\
\text { Rep. } \\
2\end{array}$ & $25,821,127$ & $24,703,495$ & $22,850,212$ & $92.5 \%$ & $21.9 \%$ \\
\hline $\begin{array}{l}\text { WT } \\
\text { Rep. } \\
1\end{array}$ & $29,622,968$ & $28,820,576$ & $26,128,040$ & $90.7 \%$ & $28.4 \%$ \\
\hline $\begin{array}{l}\text { WT } \\
\text { Rep. } \\
2\end{array}$ & $41,178,096$ & $39,935,755$ & $35,825,728$ & $89.7 \%$ & $28.2 \%$ \\
\hline
\end{tabular}

Each treatment was composed of two biological replicates (PGL: PGL Rep. 1, PGL Rep. 2; WT: WT Rep. 1, WT Rep. 2)

aligning to a single location in the apple genome v1.0 ranged from 21.9\% (PGL replicate 2) to 30.3\% (PGL replicate 1), agreeing with other apple transcriptome studies (Gusberti et al. 2013; Bai et al. 2014).

After filtering, clean reads were processed with the Cufflinks-edgeR pipeline to find genes expressed in PGL and WT cotyledons. When reads from all four libraries were analyzed with edgeR, 21,888 transcripts were detected. 3723 had differential expression, with a $P$ value $<9.9 \mathrm{E}^{-5}$, representing $17 \%$ of expressed cotyledon genes. The edgeR program measures transcript abundance in counts per million (CPM) mapped reads. Instead of analyzing all 3723 transcripts, only the most highly differentially expressed genes, with a false discovery rate (FDR) $<9.9 \mathrm{E}^{-35}$ (200 genes), were selected for further processing and analysis (Supplementary material; Table S1).

\section{Quantitative PCR validation of RNA sequencing}

Quantitative PCR (Q-PCR) was used to validate the RNA-seq data. From the 200 genes with the most differential expression based on RNA-seq, 14 transcripts were validated independently with Q-PCR. Genes were chosen due to the large differences in expression between WT and PGL and because of interesting predicted functions (Supplementary material; Table S2). ACTIN (MDP0000912745) was used to normalize transcript accumulation.

Transcript accumulation changes were consistent between Q-PCR and RNA-seq experiments for all 14 genes. Figure S2 and Table S3 (Supplementary material) show the expression values of genes for the Q-PCR experiment expressed in normalized relative quantification (NRQ) along with counts per million (CPM) values of the RNA-seq experiment. Although units differ between the two methods, for the majority of genes, the ratios of average PGL transcript accumulation to average WT transcript accumulation were in strong agreement. However, for three genes, ABSCISIC ACID 8'HYDROXYLASE 4 (MDP0000037814), MAJOR ALLERGEN MAL-D 1 (MDP0000294379), and NADPDEPENDENT D-SORBITOL-6-PHOSPHATE DEHYDROGENASE 2 (MDP 0000251531 / MDP0000133306/MDP0000758881), the ratio of PGL and WT transcript accumulation was less for Q-PCR as compared to RNA-seq.

The agreement between Q-PCR and RNA-seq data is presented in Fig. 2, where the $\log 2$ ratios of transcript accumulation values (CPM for RNA-seq and NRQ for Q-PCR) for PGL and WT samples are graphed. The $R^{2}$ value for the line of best fit is 0.88 , indicating that RNA-seq results accurately represent transcript abundance in PGL and WT cotyledons.

\section{Gene ontology analysis of differentially accumulated transcripts}

Gene ontology (GO) analysis was performed in Blast2GO on the 200 most differentially expressed genes to determine overand underrepresented terms (Götz et al. 2008). GO terms from the 21,888 expressed transcripts were used as the reference GO set, while those from the 200 most differentially expressed transcripts were the test set. Table 2 presents the 30 most under- or overrepresented GO terms with an FDR $<9.9 \mathrm{E}^{-2}$. Most GO terms were overrepresented, with only two underrepresented ("cellular protein metabolic process" and "cellular macromolecule metabolic process"). GO terms relating to the cell wall ("plant-type cell wall organization," "cell wall organization," "plant-type cell wall organization or biogenesis," and "cell wall organization or biogenesis") and transcriptional regulation ("sequence-specific double-stranded DNA binding," "transcription regulatory region DNA binding," "transcription regulatory region sequence-specific DNA binding," "regulatory region DNA binding," and "regulatory region nucleic acid binding") are especially overrepresented in Table 2.

\section{Expression of genes in the phylloquinone biosynthesis pathway}

The nine genes for phylloquinone (PhQ) biosynthesis were analyzed and only one, a MenB paralog (MDP0000797914) was differentially regulated, with transcripts more abundant in PGL (Supplementary material; Table S4) (Van Oostende et al. 2011). 


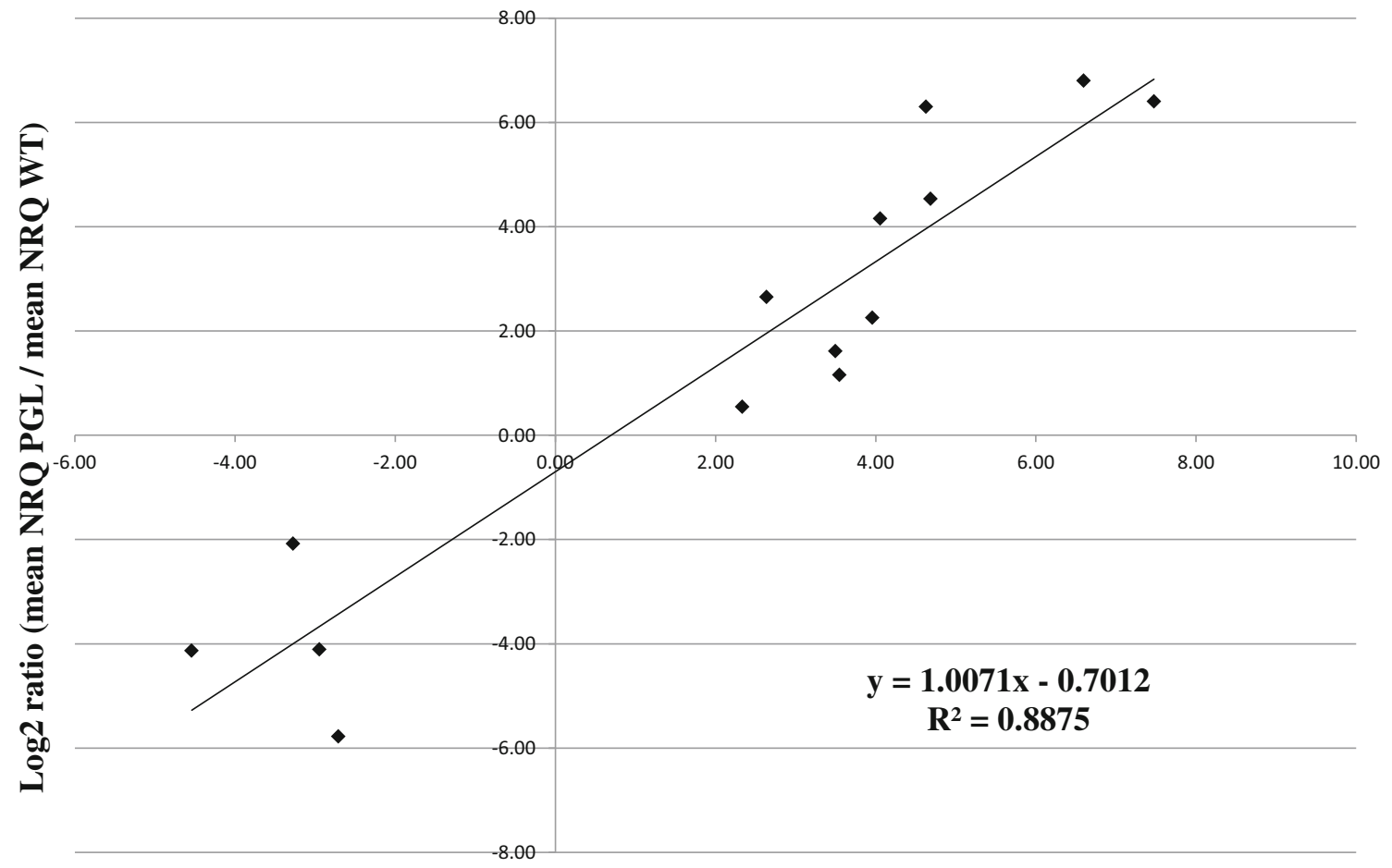

$\log 2$ ratio (mean CPM PGL / mean CPM WT)

Fig. 2 Comparing expression between RNA-seq and Q-PCR experiments. The $\log 2$ ratios of expression from the 14 tested genes were plotted for the two methods. The $R^{2}$ value for the line of best fit is 0.88 indicating that there is strong agreement in expression between both experiments

\section{Expression of chlorophyll-related genes}

Pale green lethal disorder is characterized by reduced chlorophyll content (Orcheski et al. 2015). Transcripts of chlorophyll binding, biosynthesis, and degradation genes were analyzed to determine if the PGL mutation affects their expression.

Chlorophyll synthesis Transcripts for 21 chlorophyll biosynthesis enzymes and enzyme subunits encoded by 51 genes were detected in apple (Supplementary material; Table S5), representing all enzymes and subunits in the chlorophyll biosynthesis pathway (Stenbaek and Jensen $2010)$. Of the 51 transcripts analyzed, PORPHOBILINOGEN DEAMINASE (MDP0000144555), MAGNESIUM PROTOPORPHYRIN METHYLTRANSFERASE (MDP0000489011), and MAGNESIUM CHELATASE SUBUNIT I2 (MDP0000639820) differed significantly in expression, all greater in PGL.

Chlorophyll-binding proteins Arabidopsis has 21 LIGHTHARVESTING CHLOROPHYLL A/B-BINDING (LHC) genes, while apple has 25 (Dall'Osto et al. 2015). These 25 genes are homologous to 15 Arabidopsis LHC genes based on a tBLASTx search (Supplementary material; Table S6). LHC genes are highly expressed in PGL and WT, nine with CPM values above 3000 . Only two of the 25 genes had differential expression, with LHCB4.3 (MDP0000132360) more abundant in PGL than WT and LHCB1 (MDP0000182265) more abundant in WT than PGL.

Chlorophyll breakdown Chlorophyll a and b are catabolized in the chloroplast in a series of four enzymatic steps (Christ and Hörtensteiner 2014). The four genes encoding the enzymatic steps are annotated in the apple genome v1.0 (Supplementary material; Table S7). Two enzymes were encoded by multiple copies: three for CHLOROPHYLL(IDE) B REDUCTASE and five for CHLOROPHYLLASE. Of the ten apple genes encoding the four enzymes, only PHEOPHORBIDE A OXYGENASE (MDP0000315206) had differential expression and was very abundant in WT.

\section{Expression of sorbitol-related genes}

Transcript accumulation of sorbitol transport, synthesis, and catabolism genes was compared between PGL and WT. Apple 
Table 2 Results of the Blast2GO program

\begin{tabular}{|c|c|c|c|c|c|c|}
\hline $\begin{array}{l}\text { Gene } \\
\text { ontology ID }\end{array}$ & Gene ontology term & $\begin{array}{l}\text { Single } \\
\text { test } P \\
\text { value }\end{array}$ & $\begin{array}{l}\text { FDR } \\
(Q- \\
\text { value })\end{array}$ & $\begin{array}{l}\text { Test } \\
\text { group } \\
\text { number }\end{array}$ & $\begin{array}{l}\text { Reference } \\
\text { group } \\
\text { number }\end{array}$ & $\begin{array}{l}\text { Over- or } \\
\text { underrepresented }\end{array}$ \\
\hline GO:0005576 & Extracellular region & $1.8 \mathrm{E}-10$ & $9.0 \mathrm{E}-07$ & 11 & 71 & Over \\
\hline GO:0009664 & $\begin{array}{l}\text { Plant-type cell wall } \\
\text { organization }\end{array}$ & $1.7 \mathrm{E}-08$ & $4.2 \mathrm{E}-05$ & 6 & 14 & Over \\
\hline GO:0071555 & Cell wall organization & $3.9 \mathrm{E}-06$ & $6.1 \mathrm{E}-03$ & 6 & 41 & Over \\
\hline GO:0071669 & $\begin{array}{l}\text { Plant-type cell wall } \\
\text { organization or } \\
\text { biogenesis }\end{array}$ & $4.9 \mathrm{E}-06$ & $6.1 \mathrm{E}-03$ & 6 & 43 & Over \\
\hline GO:0005975 & $\begin{array}{l}\text { Carbohydrate } \\
\text { metabolic process }\end{array}$ & $1.2 \mathrm{E}-05$ & $1.2 \mathrm{E}-02$ & 22 & 852 & Over \\
\hline GO:0004553 & $\begin{array}{l}\text { Hydrolase activity, } \\
\text { hydrolyzing } \\
\text { O-glycosyl } \\
\text { compounds }\end{array}$ & $2.3 \mathrm{E}-05$ & $1.7 \mathrm{E}-02$ & 11 & 247 & Over \\
\hline GO:0045229 & $\begin{array}{l}\text { External } \\
\text { encapsulating } \\
\text { structure } \\
\text { organization }\end{array}$ & $2.4 \mathrm{E}-05$ & $1.7 \mathrm{E}-02$ & 6 & 58 & Over \\
\hline GO:0008234 & $\begin{array}{l}\text { Cysteine-type } \\
\text { peptidase activity }\end{array}$ & $3.2 \mathrm{E}-05$ & $2.0 \mathrm{E}-02$ & 5 & 36 & Over \\
\hline GO:0016798 & $\begin{array}{l}\text { Hydrolase activity, } \\
\text { acting on glycosyl } \\
\text { bonds }\end{array}$ & $4.1 \mathrm{E}-05$ & $2.1 \mathrm{E}-02$ & 11 & 264 & Over \\
\hline GO:0044267 & $\begin{array}{l}\text { Cellular protein } \\
\text { metabolic process }\end{array}$ & $4.2 \mathrm{E}-05$ & $2.1 \mathrm{E}-02$ & 7 & 2630 & Under \\
\hline GO:0004097 & $\begin{array}{l}\text { Catechol oxidase } \\
\text { activity }\end{array}$ & $5.8 \mathrm{E}-05$ & $2.6 \mathrm{E}-02$ & 3 & 6 & Over \\
\hline GO:0016491 & $\begin{array}{l}\text { Oxidoreductase } \\
\text { activity }\end{array}$ & $1.0 \mathrm{E}-04$ & $4.3 \mathrm{E}-02$ & 26 & 1274 & Over \\
\hline GO:0045735 & $\begin{array}{l}\text { Nutrient reservoir } \\
\text { activity }\end{array}$ & $1.5 \mathrm{E}-04$ & $5.5 \mathrm{E}-02$ & 3 & 9 & Over \\
\hline GO:0048046 & Apoplast & $1.7 \mathrm{E}-04$ & $5.5 \mathrm{E}-02$ & 4 & 27 & Over \\
\hline GO:0044260 & $\begin{array}{l}\text { Cellular } \\
\text { macromolecule } \\
\text { metabolic process }\end{array}$ & $1.7 \mathrm{E}-04$ & $5.5 \mathrm{E}-02$ & 27 & 5285 & Under \\
\hline GO:0055114 & $\begin{array}{l}\text { Oxidation-reduction } \\
\text { process }\end{array}$ & $2.3 \mathrm{E}-04$ & $5.5 \mathrm{E}-02$ & 24 & 1188 & Over \\
\hline GO:0071554 & $\begin{array}{l}\text { Cell wall organization } \\
\text { or biogenesis }\end{array}$ & $2.3 \mathrm{E}-04$ & $5.5 \mathrm{E}-02$ & 7 & 129 & Over \\
\hline GO:1,990,837 & $\begin{array}{l}\text { Sequence-specific } \\
\text { double-stranded } \\
\text { DNA binding }\end{array}$ & $2.4 \mathrm{E}-04$ & $5.5 \mathrm{E}-02$ & 3 & 11 & Over \\
\hline GO:0044212 & $\begin{array}{l}\text { Transcription } \\
\text { regulatory region } \\
\text { DNA binding }\end{array}$ & $2.4 \mathrm{E}-04$ & $5.5 \mathrm{E}-02$ & 3 & 11 & Over \\
\hline GO:0000976 & $\begin{array}{l}\text { Transcription } \\
\text { regulatory region } \\
\text { sequence-specific } \\
\text { DNA binding }\end{array}$ & $2.4 \mathrm{E}-04$ & $5.5 \mathrm{E}-02$ & 3 & 11 & Over \\
\hline GO:0000975 & $\begin{array}{l}\text { Regulatory region } \\
\text { DNA binding }\end{array}$ & $2.4 \mathrm{E}-04$ & $5.5 \mathrm{E}-02$ & 3 & 11 & Over \\
\hline GO:0001067 & $\begin{array}{l}\text { Regulatory region } \\
\text { nucleic acid } \\
\text { binding }\end{array}$ & $2.4 \mathrm{E}-04$ & $5.5 \mathrm{E}-02$ & 3 & 11 & Over \\
\hline GO:0044710 & $\begin{array}{l}\text { Single-organism } \\
\text { metabolic process }\end{array}$ & $3.0 \mathrm{E}-04$ & $6.5 \mathrm{E}-02$ & 49 & 3269 & Over \\
\hline GO:0009055 & $\begin{array}{l}\text { Electron carrier } \\
\text { activity }\end{array}$ & $4.2 \mathrm{E}-04$ & $8.2 \mathrm{E}-02$ & 10 & 292 & Over \\
\hline GO:0003824 & Catalytic activity & $4.3 \mathrm{E}-04$ & $8.2 \mathrm{E}-02$ & 87 & 7116 & Over \\
\hline GO:0009835 & Fruit ripening & $4.5 \mathrm{E}-04$ & $8.2 \mathrm{E}-02$ & 3 & 14 & Over \\
\hline GO:0071695 & & $4.5 \mathrm{E}-04$ & $8.2 \mathrm{E}-02$ & 3 & 14 & Over \\
\hline
\end{tabular}


Table 2 (continued)

\begin{tabular}{|c|c|c|c|c|c|c|}
\hline $\begin{array}{l}\text { Gene } \\
\text { ontology ID }\end{array}$ & Gene ontology term & $\begin{array}{l}\text { Single } \\
\text { test } P \\
\text { value }\end{array}$ & $\begin{array}{l}\text { FDR } \\
(Q- \\
\text { value })\end{array}$ & $\begin{array}{l}\text { Test } \\
\text { group } \\
\text { number }\end{array}$ & $\begin{array}{l}\text { Reference } \\
\text { group } \\
\text { number }\end{array}$ & $\begin{array}{l}\text { Over- or } \\
\text { underrepresented }\end{array}$ \\
\hline & $\begin{array}{l}\text { Anatomical structure } \\
\text { maturation }\end{array}$ & & & & & \\
\hline GO:0015695 & $\begin{array}{l}\text { Organic cation } \\
\text { transport }\end{array}$ & $4.8 \mathrm{E}-04$ & $8.2 \mathrm{E}-02$ & 2 & 2 & Over \\
\hline GO:0010154 & Fruit development & $4.8 \mathrm{E}-04$ & $8.2 \mathrm{E}-02$ & 5 & 67 & Over \\
\hline GO:0044711 & $\begin{array}{l}\text { Single-organism } \\
\text { biosynthetic } \\
\text { process }\end{array}$ & $5.0 \mathrm{E}-04$ & $8.3 \mathrm{E}-02$ & 24 & 1242 & Over \\
\hline
\end{tabular}

The table presents the 30 gene ontology terms that were found to be over- or underrepresented in differential expression between wild-type and pale green lethal samples. Most of the GO terms are overrepresented

contains two NADP-SORBITOL-6-PHOSPHATE DEHYDROGENASE $(S 6 P D H)^{1}$, three SUCROSEPHOSPHATE PHOSPHATASE (SPP), 13 SORBITOL DEHYDROGENASE (SDH), and over 20 putative SORBITOL TRANSPORTER (SOT) genes (Supplementary material; Table S8) (Wu et al. 2015).

$S 6 P D H, S D H, S P P$, and $S O T$ expression was detected in PGL and WT (Supplementary material; Table S8). Of the two $S 6 P D H$ genes, only $S 6 P D H-2$ had differential expression, which was confirmed with Q-PCR (Supplementary material; Fig. S2). S6PDH-1 on chromosome 10 had moderate accumulation. Transcripts were detected for eight of $13 \mathrm{SDH}$ genes. The three $S D H$ transcripts with differential expression were all more abundant in PGL. The expression difference was greatest with SDH-1 (MDP0000250546) on chromosome 1 , and its transcript abundance was confirmed with Q-PCR (Supplementary material; Fig. S2). All three SPP genes were expressed in cotyledons, with no difference in expression. Expression of 11 of 22 SOT genes was detected and two had differential transcript accumulation. SOT-1 (MDP0000940086) on chromosome 1 had greater expression in PGL, while SOT-14 (MDP0000279249/MDP0000841918) on chromosome 12 was expressed more in WT.

\section{Cotyledon abscisic acid content}

Abscisic acid (ABA) was measured in PGL and WT cotyledons using liquid chromatography-mass spectrometry/mass

\footnotetext{
${ }^{1}$ We noted that the number of unique $S 6 P D H$ genes determined by Velasco et al. (2010) is overestimated in the apple genome v1.0 annotation. The four predicted S6PDH transcripts MDP0000408705, MDP0000361351, MDP0000818877, and MDP0000639894 are identical and map to the same location on chromosome 10, and are likely the same gene. They comprise a S6PDH paralog that for simplicity is called S6PDH-1. MDP0000133306, MDP0000251531, and MDP0000758881 are three predicted S6PDH transcripts that are unanchored and identical, indicating they are the same gene. They comprise a second $S 6 P D H$ paralog that is called $S 6 P D H$-2. Instead of seven $S 6 P D H$ genes, apple only has two: $S 6 P D H-1$ and $S 6 P D H-2$.
}

spectrometry (LC-MS/MS). ABA samples were measured in duplicate biological replicates, pooling three cotyledons as with the RNA isolation for RNA-seq (Supplementary material; Fig. S1). Fresh weight ABA concentration was $20.6 \mathrm{pmol} /$ $\mathrm{g}$ for PGL and $131.4 \mathrm{pmol} / \mathrm{g}$ for WT.

\section{Discussion}

\section{Regulation of phylloquinone and chlorophyll genes}

Differential expression of chlorophyll binding, synthesis, and degradation genes does not explain chlorophyll reduction in PGL seedlings. Chlorophyll synthesis genes like PORPHOBILINOGEN DEAMINASE and MAGNESIUM PROTOPORPHYRIN METHYLTRANSFERASE were expressed more in PGL, while the chlorophyll catabolism gene PHEOPHORBIDE A OXYGENASE was expressed more in WT (Supplementary material; Table S5; Table S7). Of the 25 LHC genes expressed in apple, only MDP0000182265 ( $L H C B 1$ ) had lower transcript abundance in PGL (Supplementary material; Table S6). However, $\mathrm{Xu}$ et al. (2012) demonstrated that Arabidopsis LHCB1 T-DNA knockouts did not lose chlorophyll. Other LHC proteins likely compensate to maintain chlorophyll-binding capacity, suggesting LHCB1 expression minimally impacts chlorophyll content. The pattern of chlorophyll-related gene expression suggests that differences in chlorophyll content might be explained by these genes being under translational or post-translational control, or that pleiotropy may limit resources available for chlorophyll production in PGL seedlings.

The mutant MdPHYLLO gene that causes PGL had little effect on expression of PhQ biosynthetic genes. Only MenB (MDP0000797914) had altered expression, with greater transcript abundance in PGL (Supplementary material; Table S4). The increased expression of MenB in PGL seedlings may be an attempt by these plants to increase PhQ content. It is 
unclear if MenB catalyzes a rate-limiting step or is involved with feedback regulation of $\mathrm{PhQ}$ production due to a lack of understanding of the gene's regulation or the enzyme's kinetics (Reumann 2013). MenB is one of three enzymes in the PhQ pathway located in the peroxisome (along with MenE and DHNAT), and as such, it may control the rate at which $\mathrm{PhQ}$ precursors are made and transferred back to the chloroplast for the final three enzymatic reactions (Reumann 2013).

\section{Pale green lethal seedling response to light stress}

An EARLY LIGHT INDUCIBLE PROTEIN 1 (ELIP1; MDP0000840536) gene had greater expression in PGL cotyledons (Supplementary material; Table S1). ELIP1, which binds chlorophyll, is a member of the $L H C$ gene family and is upregulated in response to high light conditions. It is proposed to act in a photoprotective function under light stress to prevent photooxidative damage. ELIP overexpression reduced photooxidative damage when expressed in an Arabidopsis chlorophyll-deficient mutant (Hutin et al. 2003). The upregulation of ELIP1 in PGL cotyledons may be a response to light stress caused by reduced chlorophyll levels.

\section{Pale green lethal seedling response to carbohydrate starvation}

PGL seedlings cannot photosynthesize, and stored carbohydrates are rapidly depleted during germination, so seedlings are under carbohydrate starvation. Transcriptional regulation of starvation response genes in PGL seedlings suggests that mechanisms to ensure sufficient carbohydrate for cotyledons may occur at the expense of other organs. The bZIP63 gene (MDP0000270365), induced by low glucose levels and an important component of the Arabidopsis sugar starvation signaling pathway, is upregulated in PGL seedlings (Matiolli et al. 2011). Reserving available carbohydrate for cotyledons might explain the poor development of roots and true leaves (Fig. 1).

Sorbitol is a polyol sugar serving as the main translocatable carbohydrate in rosaceous fruit trees (Wu et al. 2015). Sorbitol is produced from glucose by SORBITOL-6-PHOSPHATE DEHYDROGENASE (S6PDH) in source organs (leaves and cotyledons) and then transported by SORBITOL TRANSPORTER (SOT) proteins to sink organs (a growing organ) (Wu et al. 2015). SORBITOL DEHYDROGENASE (SDH) converts sorbitol to fructose in sink organs. In a photosynthesizing organ such as a cotyledon, $S 6 P D H$ expression is expected to be high so that photosynthate can be converted to sorbitol for transport to sink organs. $S D H$ expression is expected to be low so that sorbitol produced by S6PDH is not immediately converted into fructose by SDH.

This expected regulation of key sorbitol metabolism transcripts (high $S 6 P D H$ and low $S D H$ ) is not observed in the PGL transcriptome. Rather, $S D H$ transcript accumulation is greater in PGL cotyledons, while S6PDH transcript accumulation is much lower (Supplementary material; Table S8). This gene regulation suggests that sorbitol is not being produced in PGL seedlings for transport out of the cotyledons and that any sorbitol present is converted to fructose and remains in the source organ. This enzyme regulation may ensure that all available carbohydrate stays in cotyledons so they will have resources to maintain the photosynthetic machinery and recover from starvation stress.

Plant and fungi cell walls can become a source of carbohydrate during starvation stress (Lee et al. 2007; Van Munster et al. 2015). Glycosyl hydrolase enzymes are induced by starvation in Arabidopsis, and Lee et al. (2007) proposed these enzymes scavenge carbohydrate from the cell wall. Transcripts for genes encoding three glycosyl hydrolase enzymes, $\beta$-GALACTOSIDASE (MDP0000416548 and MDP 0000127542$), \beta-D-X Y L O S I D A S E 1$ (MDP0000140483), and $\beta$-GLUCOSIDASE 12 (MDP0000940742), were much more abundant in PGL (Supplementary material; Table S1). An upregulation of glycosyl hydrolase genes suggests that cell wall carbohydrate may be a source of energy to maintain metabolic function of the cotyledon during starvation.

Sugar transporters are important for maintaining sugar homeostasis under energy-limiting conditions (Contento et al. 2004). In Arabidopsis, SUGAR TRANSPORTER 1 (STP1; AT1G11260) is the principal transporter of extracellular monosaccharides into the cell (Sherson et al. 2000). STP1 expression is induced by sugar starvation and its transcription decreases rapidly when plants are provided with sugar (Cordoba et al. 2015). In Arabidopsis, SUGAR TRANSPORTER 13 (STP13; AT5G26340) is upregulated in salt-stressed roots and during wounding to import extracellular sugars back into cells. Overexpression of STP13 increases cellular carbohydrate uptake in Arabidopsis, improving growth rate (Schofield et al. 2009). MDP0000288533 and MDP0000193050, apple orthologs of STP1 and STP13, respectively, were upregulated in PGL. STP proteins may work in concert with the glycosyl hydrolase enzymes to ensure sufficient sugar is available to sustain PGL cotyledon metabolism.

The transcriptomic data suggests that carbohydrates do not leave PGL cotyledons and that cell wall and extracellular carbohydrates are being transported into cotyledon cells. As cotyledons are the principal photosynthetic organ of young seedlings, accumulating carbohydrates (perhaps at the expense of other organs) might be a way to reestablish cotyledon photosynthesis and recover from starvation. The maintenance of cotyledons might occur even though PGL seedlings cannot photosynthesize. 


\section{Pale green lethal seedling response to water deficit stress}

RNA-sequencing detected the upregulation of water deficit response genes in PGL cotyledons. The poor root development of PGL seedlings likely prevents adequate water transport, leading to water deficit (Fig. 1b). Cotyledons are upregulating genes to prevent water loss, as with MDP0000817733 and MDP0000817734, encoding EPIDERMIS-SECRETED SPECIFIC GLYCOPROTEIN 1 (EP1). EP1 forms an impermeable barrier to limit water loss through the epidermal cell layer (Van Engelen et al. 1993).

Transcripts encoding LATE EMBRYOGENESIS ABUNDANT (LEA; MDP0000937088 and MDP0000191415) and DEHYDRIN 1 (DHN1; MDP0000868045) proteins were abundant in PGL. These hydrophilic proteins are osmoprotectants, upregulated during water deficit to maintain the integrity of protein structures and membranes during desiccation (Hundertmark and Hincha 2008; Radwan et al. 2014). LEA and DHN1 transcript accumulation suggests water deficit might compromise the integrity of proteins and membranes. Apple upregulates DEHYDRIN expression during drought and cold acclimation (a stress also affecting water relations) (Wisniewski et al. 2008; Falavigna et al. 2015). Little is known about the function and regulation of apple $L E A$ genes.

Increasing cell wall extensibility during drought allows shoots to continue growth even under reduced turgor, and allows roots to grow and find soil moisture (Miedes et al. 2013; Clauw et al. 2015). Two proteins controlling cell wall extensibility are EXPANSIN (EXP) and XYLOGLUCAN ENDOTRANSGLUCOSYLASE/HYDROLASE (XTH) (Cosgrove 2016).

EXP non-enzymatically disrupts non-covalent bonds between hemicellulose and crystalline cellulose microfibrils (Sasidharana et al. 2011). XTH enzymatically cleaves xyloglucans connecting cellulose fibrils and remodels the cell wall following loosening (Cosgrove 2016). EXP and XTH genes are abundant in the apple genome, but their function during abiotic stress is not well understood. Transcripts encoding six EXP genes (especially MDP0000681724) and an XTH (MDP0000323987) were highly abundant in PGL (Supplementary material; Table S9). The upregulation of these genes suggests that increasing cell wall extensibility is an important component of the apple water deficit stress response.

The disaccharide trehalose ( $\alpha$-d-glucopyranosyl-1,1-a-dglucopyranoside) is an osmoprotectant and compatible solute, important for water deficit response in bacteria, fungi, and plants (Delorge et al. 2014; Tapia et al. 2015). Drought and cold stimulate expression of trehalose synthesis genes and production of trehalose in some crops, including wheat and cotton (Kosmas et al. 2006; Iqbal et al. 2012). Application of exogenous trehalose confers drought tolerance in several Brassica species (Alam et al. 2014).
Seven transcripts encoding TREHALOSE-6-PHOSPHATE SYNTHASE (TPS) genes were detected in PGL, and five had differential expression. Two TPS genes (MDP0000799020 and MDP0000135837) were among the most highly differentially expressed (Supplementary material; Table S1; Table S10). While the exact function of trehalose is not well understood in apple, the upregulation of multiple TPS genes in PGL suggests their expression is an important component of the water deficit response.

The water deficit response involves the activation and repression of a large suite of genes, a process controlled by drought-responsive transcription factors (Todaka et al. 2015). One such gene is RELATED TO AP2 6L (RAP2.6L), a member of the ethylene response factor family. In Arabidopsis, expression of this transcription factor is activated by water deficit stress, and transgenic plants overexpressing $R A P 2.6 L$ are better able to recover from drought after being rewatered, as compared with WT plants (Krishnaswamy et al. 2011). The apple ortholog of RAP2.6L, MDP0000316694, was upregulated in PGL seedlings suggesting this transcription factor is also an important component of the water deficit response in apple.

\section{Genes promoting senescence are downregulated in pale green lethal seedlings}

Senescence is the controlled death and recycling of a plant organ and may be genetically programmed in transient organs such as cotyledons and petals (Shibuya and Ichimura 2016), or triggered by unfavorable environmental conditions (Gepstein and Glick 2013). Massive reprogramming of gene expression occurs during the initiation and progression of senescence (Breeze et al. 2011). As PGL seedlings are growing under adverse conditions (starvation and water deficit stresses), their cotyledons may be undergoing premature senescence to mobilize resources to roots or true leaves. However, transcriptomic data suggests that PGL seedlings have delayed cotyledon senescence compared to WT. Transcripts of genes associated with the promotion and progression of senescence were downregulated in PGL cotyledons, such as the transcription factor NAC1 (MDP0000298182) (Kim et al. 2011). We propose that as a response to carbohydrate deprivation, PGL seedlings maintain their cotyledons (a young seedling's primary photosynthetic organ) in an effort to produce carbohydrate and recover from starvation. This occurs despite PGL seedlings' inability to photosynthesize due to the MdPHYLLO mutation (Orcheski et al. 2015).

The phytohormone abscisic acid (ABA) is important in drought stress response, increasing in concentration during water deficit (Jiang and Zhang 2002) and stimulating closure of stomata to prevent water loss (Lind et al. 2015). ABA levels were expected to be high in PGL cotyledons because of water deficit stress, yet they had six times less ABA than WT. PGL 
seedlings are not increasing ABA content in response to water deficit.

ABA is involved with the onset of senescence, during which endogenous ABA content increases and ABA synthesis genes are activated (Finkelstein 2013). ABA is required for the breakdown of chlorophyll, an important first step in photosynthetic organ senescence. Yang et al. (2014) discovered that ABA content in Arabidopsis is lowered by a loss-offunction mutation in transcription factor $N A C-L I K E$ ACTIVATED BYAP3/PI (NAP), an activator of the ABA biosynthetic gene ABSCISIC ACID ALDEHYDE OXIDASE 3 (AAO3). They demonstrated that low ABA concentration reduced the expression of several chlorophyll-degrading genes including STAY GREEN, and slowed chlorophyll breakdown (yellowing) during dark-induced senescence.

STAY GREEN promotes the onset of leaf senescence by initiating chlorophyll removal (Hörtensteiner 2009; Thomas and Ougham 2014). It binds to the light-harvesting complex II, recruiting chlorophyll-degrading enzymes so chlorophyll is removed and catabolized (Sakuraba et al. 2012). STAY GREEN (MDP0000322543) transcripts were barely detectable in PGL but abundant in WT (Supplementary material; Fig. S2, Table S1). The lack of ABA in PGL cotyledons may be responsible for reduced STAY GREEN expression and indicates photosystem disassembly and chlorophyll degradation has not begun.

The upregulation of ABA catabolism genes may explain the difference in ABA content between PGL and WT. Transcripts for three genes involved in ABA inactivation and transport were abundant in PGL. These genes encode ABSCISIC ACID 8'-HYDROXYLASE (ABAH, which breaks down ABA; MDP0000037814), URIDINE DIPHOSPHATE GLUCOSYL TRANSFERASE $71 \mathrm{~B} 6$ (UGT71B6, an ABA conjugator; MDP0000307237), and NITRATE TRANSPORTER 1.2 (NRT1.2, an ABA transporter; MDP0000281790) (Kushiro et al. 2004; Kanno et al. 2012; Dong and Hwang 2014).

Senescence releases metal ions, which can become cofactors for enzymes that produce harmful reactive oxygen species (ROS) (Guo et al. 2003; Landi 2015). Plants produce metalchelating and transport proteins to capture and move these harmful ions out of the organ (Hassinen et al. 2011). Transcripts for two such genes, METALLOTHIONEIN $2 A$ (MT2A; MDP0000153123) and COPPER CHAPERONE PROTEIN (CCH; MDP0000201775), were abundant in WT, but very low in PGL. MT2A is a metal-chelating protein that binds copper ions (Benatti et al. 2014), while CCH transports copper ions out of the cell (Tehseen et al. 2010).

Members of the cysteine-type family of proteases are upregulated during leaf senescence (Esteban-Garcia et al. 2010; Parrott et al. 2010). Transcripts encoding four cysteine-type proteases were abundant in WT but not PGL. MDP0000218404, MDP0000311720, and MDP0000764121 are three orthologs of the Arabidopsis SENESCENCE ASSOCIATED GENE 2 (SAG2; AT5G60360), while MDP0000643283 is the ortholog of Arabidopsis CYSTEINE ENDOPEPTIDASE 1 (CEP1; AT5G50260), which is involved in programmed cell death (Zhang et al. 2014). The expression of senescence-associated cysteine-protease genes in WT suggests that senescence has begun in WT, but not in PGL.

Some genes slow the onset of senescence, including TANDEM ZINC FINGER PROTEIN 1 (TZF1), which regulates gene activity by binding RNA (Fukao et al. 2012; Jan et al. 2013; Qu et al. 2014; Zhou et al. 2014). TZF1 expression is induced by stress, and its overexpression confers stress tolerance and significantly delays leaf senescence in rice and Arabidopsis (Jan et al. 2013; Zhou et al. 2014). Delayed senescence appears to result from the downregulation of numerous senescence-associated genes, perhaps by TZF1-mediated decay of their RNAs (Jan et al. 2013). An apple ortholog of TZF1 (MDP0000501598) had much greater expression in PGL, suggesting that apple $T Z F 1$ expression may be induced to postpone senescence.

\section{Conclusion}

RNA sequencing was used to compare cotyledon transcriptomes of pale green lethal and wild-type apple seedlings, with nearly 4000 genes showing differences in transcript abundance between the two treatments. Many metabolic and physiological processes relating to stress response, including starvation, water deficit, and senescence, appear affected by PGL disorder. Some differences in gene regulation are related to conserved stress responses, such as the upregulation of putative osmoprotectant proteins caused by water deficit. Transcriptome data indicated that some changes to physiology and metabolism might be unique to apple, including altered sorbitol production and transport, and delayed cotyledon senescence. This research provides insight into a lethal genetic disorder and demonstrates that some adaptation mechanisms may be plant- or lineage-specific.

\section{Experimental procedures}

\section{Plant materials}

Seeds from the same cross used to map the pale green lethal locus (Orcheski et al. 2015) were germinated to provide cotyledon tissue for the RNA-seq and Q-PCR experiments. This cross was made in 2012 between two advanced selections that are confirmed PGL carriers. Enough seedlings were germinated to provide separate tissue for the RNA-seq, Q-PCR, and ABA experiments. Seedlings were grown in the greenhouse 
under $14 \mathrm{~h}$ light at $22^{\circ} \mathrm{C}$ and $10 \mathrm{~h}$ dark at $18^{\circ} \mathrm{C}$ with ambient humidity.

\section{RNA isolation}

Total RNA was harvested from cotyledons of 2-week-old seedlings for the RNA-seq and Q-PCR experiments. Cotyledons from six seedlings of both WT and PGL were excised, and each cotyledon went into a separate tube to make two biological replicates (Supplementary material; Fig. S1). The pooled cotyledons were immediately flash frozen in liquid nitrogen and stored at $-80{ }^{\circ} \mathrm{C}$ until RNA extraction. Total RNA was isolated from cotyledons using the Spectrum Plant Total RNA Kit (Sigma Aldrich, St. Louis, MO). All six cotyledons from a tube were ground to a fine powder in liquid nitrogen using a mortar and pestle, and $100 \mathrm{mg}$ of tissue powder was weighed out for the isolation.

\section{Library preparation and high-throughput sequencing}

Sequencing libraries for single-end Illumina sequencing were prepared in the Giovannoni Lab at the Boyce Thompson Institute for Plant Research (Ithaca, NY). Library preparation followed the protocol in Zhong et al. (2011). For each library, the cDNA was ligated to an Illumina TruSeq adapter containing a unique six-nucleotide index sequence. The four libraries were pooled into a single sample for sequencing at Cornell University's Weill Medical School Core Facility (New York, NY). The Illumina HiSEQ2000 platform was used to sequence the reads from a single end for 101 cycles. Sequenced reads in the fastq format were demultiplexed into the four original libraries at the Core Facility.

\section{Bioinformatics}

Raw read quality was determined with the fastqc program (bioinformatics.babraham.ac.uk/projects/fastqc/), and the reads were processed with the fastq-mcf (https://code. google.com/p/ea-utils/) program to remove adapter sequence, reads $<50 \mathrm{nt}$, and reads with a $Q$-score $<30$.

Quality reads were aligned to the 'Golden Delicious' apple genome v1.0 with TopHat v2.1.0 using default parameters (Trapnell et al. 2010; Velasco et al. 2010). Apple genome v1.0 gene annotations available at the Genome Database for Rosaceae (rosaceae.org) were used to determine transcript abundance with CuffDiff v2.2.1 (Trapnell et al. 2010).

The "genes.read group tracking" output file from CuffDiff estimates the number of full-length transcripts of each gene originally present in the four libraries. A custom perl script developed at the Cornell Computational Biology Service Unit converted "genes.read_group_tracking" into two tab-delimited text files that can be loaded into an $\mathrm{R}$ data table. These files were used to determine differential gene expression using edgeR for an experiment with two biological replicates (Robinson et al. 2010).

\section{Gene ontology analysis}

Gene ontology (GO) terms of the apple gene annotations were provided by Dr. S. Strickler at the Boyce Thompson Institute for Plant Research. The GO terms from the 21,888 expressed genes were the reference list, while GO terms for the top 200 differentially expressed transcripts comprised the test list. Functional enrichment was performed with Blast2GO using Fisher's exact test. A $P$ value filter was set to 0.01 . A two-sided test was used to identify both overrepresented and underrepresented functional categories.

\section{Quantitative PCR primer design}

Transcript sequences of genes analyzed with Q-PCR were extracted from the apple genome v1.0 using the Cufflinks gffread function. A BLASTn search of transcripts against the GDR database was performed to identify paralogs (Supplementary material; Table S11). To choose Q-PCR primer positions, transcript (coding sequence), gene (introns and exons), and paralog transcript sequences were aligned with MegAlign (DNAStar, Madison, WI). One primer was placed at a position to span an exon-exon boundary while the second primer was at a position with polymorphic sequence. Primers were designed to be between 18 and $26 \mathrm{nt}$, amplify a product less than $160 \mathrm{bp}$, have a Tm between 56 and $61{ }^{\circ} \mathrm{C}$, and with a Tm difference no larger than $1.2^{\circ} \mathrm{C}$. To ensure primers were errorfree and that the predicted exon-exon junctions were correct, individual primers were used for a BLASTn search to the Malus EST collection at NCBI GenBank. Only primers with $100 \%$ identity to an EST sequence and no errors at the exon-exon junction were kept. ACTIN (MDP0000912745) primers from Varkonyi-Gasic et al. (2010) were used as a positive control.

\section{Quantitative PCR protocol}

Q-PCR and data analysis were performed by ARQ Genetics (Bastrop, TX). Total RNA from the four treatments (two each PGL and WT biological replicates) was quantified and quality was determined with an Agilent 2100 Bioanalyzer (Agilent Technologies, Santa Clara, CA). One microgram of total RNA was used as template to synthesize cDNA with the High Capacity cDNA Reverse Transcription Kit (Applied Biosystems, Waltham, MA) with a reaction volume of $50 \mu \mathrm{l}$. Random hexamers were used to prime synthesis of cDNA. 
Q-PCR was performed on the ABI 7900HT Fast Real Time PCR System (Applied Biosystems, Waltham, MA) using assays specific for each gene of interest. Each reaction well contained $5 \mu$ l of Power SYBR Green PCR Master Mix (Applied Biosystems, Waltham, MA), cDNA equivalent to $20 \mathrm{ng}$ of total RNA, and $400 \mathrm{nM}$ each of forward and reverse amplification primers in a reaction volume of $10 \mu \mathrm{l}$. Cycling conditions were: $95^{\circ} \mathrm{C}$ for $10 \mathrm{~min}$ for polymerase activation, followed by 40 cycles of $95^{\circ} \mathrm{C}$ for $15 \mathrm{~s}$ and $60^{\circ} \mathrm{C}$ for $1 \mathrm{~min}$. Data analysis was performed using Sequence Detection System v2.4 software (Applied Biosystems, Waltham, MA). The experimental $\mathrm{Ct}$ (cycle threshold) was calibrated against the endogenous control product ACTIN (MDP0000912745). Samples were analyzed for relative transcript accumulation by the $\Delta \Delta \mathrm{Ct}$ method (Pfaffl 2001). Relative quantification of transcript abundance was normalized against the wild-type replicate 2 (WR2) sample.

\section{Cotyledon abscisic acid content}

Abscisic acid (ABA) measurements were performed in the Kolomiets Lab at Texas A\&M University (College Station, TX). ABA was analyzed using an Ascentis Express 18 Column $(3 \mathrm{~cm} \times 2.1 \mathrm{~mm}, 2.7 \mu \mathrm{m})$ together with an API 3200 LC-MS/MS (Sciex, Framingham, MA) in (-) ESI mode, according to the methods of Pan et al. (2008). Isotopically labeled $\mathrm{d}_{6}$-ABA (Olchem LTD., Olomouc, Czech Republic) was used as an internal standard. ABA was extracted from 60 to $110 \mathrm{mg}$ of cotyledon tissue with $500 \mu \mathrm{l}$ extraction buffer (2-propanol:water:HCl; 2:1:0.002 v/v/v). After a shaking incubation at $4{ }^{\circ} \mathrm{C}$ for $30 \mathrm{~min}, 500 \mu \mathrm{l}$ of dichloromethane was added to the samples and they were shaken again at $4{ }^{\circ} \mathrm{C}$ for $30 \mathrm{~min}$. Samples were centrifuged at $13,000 \mathrm{~g}$ for $5 \mathrm{~min}$, and the organic phase was dried under continuous nitrogen then re-suspended with $150 \mu \mathrm{L}$ of methanol before directly injecting into LC-MS/MS.

Acknowledgments The authors would like to thank Q. Sun and A. Bombarely for their help with the bioinformatics analysis, Y. $\mathrm{Xu}$ and J. Giovannoni for help making sequencing libraries, and S. Strickler for providing Gene Ontology annotations. This work was supported by the United States Department of Agriculture, National Institute of Food and Agriculture Predoctoral Fellowship Grant - 2015-67011-22787.

\section{Compliance with ethical standards}

Conflict of interest The authors declare that they have no conflict of interest.

Data archiving statement The raw reads from the four RNA sequencing libraries (wild-type replicates 1 and 2, and pale green lethal replicates 1 and 2) are archived and publically available at the National Center for Biotechnology Information, Sequence Read Archive (NCBI; http://www. ncbi.nlm.nih.gov/sra) under BioProject PRJNA311518 or SRA SRP069858.
Open Access This article is distributed under the terms of the Creative Commons Attribution 4.0 International License (http:// creativecommons.org/licenses/by/4.0/), which permits unrestricted use, distribution, and reproduction in any medium, provided you give appropriate credit to the original author(s) and the source, provide a link to the Creative Commons license, and indicate if changes were made.

\section{References}

Alam MM, Nahar K, Hasanuzzaman M, Fujita F (2014) Trehaloseinduced drought stress tolerance: a comparative study among different Brassica species. Plant Omics 7:271-283

Bai Y, Dougherty L, Li M, Fazio G, Cheng L, Xu K (2012) A natural mutation-led truncation in one of the two aluminum-activated malate transporter-like genes at the $M a$ locus is associated with low fruit acidity in apple. Mol Gen Genomics 287:663-678

Bai Y, Dougherty L, Xu K (2014) Towards an improved apple reference transcriptome using RNA-seq. Mol Gen Genomics 289:427-438

Basu S, Ramegowda V, Kumar A, Pereira A (2016) Plant adaptation to drought stress. F1000Res 5:1554. doi:10.12688/f1000research

Benatti M, Yookongkaew N, Meetam M, Guo WJ, Punyasuk N, Abu Qamar S, Goldsbrough P (2014) Metallothionein deficiency impacts copper accumulation and redistribution in leaves and seeds of Arabidopsis. New Phytol 202:940-951

Breeze E, Harrison E, McHattie S, Hughes L, Hickman R, Hill C, Kiddle S, Kim YS, Penfold CA, Jenkins D, Zhang C, Morris K, Jenner C, Jackson S, Thomas B, Tabrett A, Legaie R, Moore JD, Wild DL, Ott S, Rand D, Beynon J, Denby K, Mead A, Buchanan-Wollaston V (2011) High-resolution temporal profiling of transcripts during Arabidopsis leaf senescence reveals a distinct chronology of processes and regulation. Plant Cell 23:873-894

Buti M, Poles L, Caset D, Magnago P, Fernandez Fernandez F, Colgan RJ, Velasco R, Sargent DJ (2015) Identification and validation of a QTL influencing bitter pit symptoms in apple (Malus $\times$ domestica). Mol Breed 35:1-11

Christ B, Hörtensteiner S (2014) Mechanism and significance of chlorophyll breakdown. J Plant Growth Regul 33:4-20

Clauw P, Coppens F, De Beuf K, Dhondt S, Van Daele T, Maleux K, Storme V, Clement L, Gonzalez N, Inzé D (2015) Leaf responses to mild drought stress in natural variants of Arabidopsis. Plant Physiol 167:800-816

Contento AL, Kim SJ, Bassham DC (2004) Transcriptome profiling of the response of Arabidopsis suspension culture cells to Suc starvation. Plant Physiol 135:2330-2347

Cordoba E, Aceves-Zamudio DL, Hernández-Bernal AF, Ramos-Vega M, León P (2015) Sugar regulation of SUGAR TRANSPORTER PROTEIN 1 (STP1) expression in Arabidopsis thaliana. J Exp Bot 66:147-159

Cosgrove DJ (2016) Plant cell wall extensibility: connecting plant cell growth with cell wall structure, mechanics, and the action of wallmodifying enzymes. J Exp Bot 67:463-476

Dall'Osto L, Bressan M, Bassi R (2015) Biogenesis of light harvesting proteins. Biochimica Biophysica Acta 1847:861-871

de Heredia UL, Vázquez-Poletti JL (2016) RNA-seq analysis in forest tree species: bioinformatic problems and solutions. Tree Genet Genomes 12:30. doi:10.1007/s11295-016-0995-X

Delorge I, Janiak M, Carpentier S, Van Dijck P (2014) Fine tuning of trehalose biosynthesis and hydrolysis as novel tools for the generation of abiotic stress tolerant plants. Front Plant Sci 5:147. doi: $10.3389 /$ fpls.2014.00147

Dong T, Hwang I (2014) Contribution of ABA UDP-glucosyltransferases in coordination of ABA biosynthesis and catabolism for ABA homeostasis. Plant Signal Behav 9:e28888. doi:10.4161/psb.28888 
Esteban-Garcia B, Garrido-Cardenas JA, Alonso DL, Garcia-Maroto F (2010) A distinct subfamily of papain-like cysteine proteinases regulated by senescence and stresses in Glycine max. J Plant Physiol 167:1101-1108

Falavigna VS, Miotto YE, Porto DD, Anzanello R, Santos HP, Fialho FB, Margis-Pinheiro M, Pasquali G, Revers LF (2015) Functional diversification of the DEHYDRIN gene family in apple and its contribution to cold acclimation during dormancy. Physiol Plant 155:315-329

Finkelstein R (2013) Abscisic acid synthesis and response. Arabidopsis Book 11:e0166

Fukao T, Yeung E, Bailey-Serres J (2012) The submergence tolerance gene SUB1A delays leaf senescence under prolonged darkness through hormonal regulation in rice. Plant Physiol 160:1795-1807

Gepstein S, Glick BR (2013) Strategies to ameliorate abiotic stressinduced plant senescence. Plant Mol Biol 82:623-633

Götz S, García-Gómez JM, Terol J, Williams TD, Nagaraj SH, Nueda MJ, Robles M, Talón M, Dopazo J, Conesa A (2008) Highthroughput functional annotation and data mining with the Blast2GO suite. Nucleic Acids Res 36:3420-3435

Gross J, Cho WK, Lezhneva L, Falk J, Krupinska K, Shinozaki K, Seki M, Herrmann RG, Meurer J (2006) A plant locus essential for phylloquinone (vitamin $\mathrm{K}_{1}$ ) biosynthesis originated from a fusion of four eubacterial genes. J Biol Chem 281:17189-17196

Guo WJ, Bundithya W, Goldsbrough PB (2003) Characterization of the Arabidopsis metallothionein gene family: tissue-specific expression and induction during senescence and in response to copper. New Phytol 159:369-381

Gusberti M, Gessler C, Broggini G (2013) RNA-seq analysis reveals candidate genes for ontogenic resistance in Malus-Venturia pathosystem. PLoS One 8:e78457. doi:10.1371/journal.pone.0078457

Hassinen VH, Tervahauta AI, Schat H, Kärenlampi SO (2011) Plant metallothioneins: metal chelators with ROS scavenging activity? Plant Biol 13:225-232

Hörtensteiner S (2009) Stay-green regulates chlorophyll and chlorophyllbinding protein degradation during senescence. Trends Plant Sci 14: $155-162$

Hundertmark M, Hincha DK (2008) LEA (late embryogenesis abundant) proteins and their encoding genes in Arabidopsis thaliana. BMC Genomics 9:118. doi:10.1186/1471-2164-9-118

Hutin C, Nussaume L, Moise N, Moya I, Kloppstech K, Havaux M (2003) Early light-induced proteins protect Arabidopsis from photooxidative stress. Proc Natl Acad Sci 100:4921-4926

Iqbal MJ, Mehoob UR, Ashraf M, Sheikh MA, Jamil A (2012) Trehalose expression in hexaploid wheat (Triticum aestivum L.) germplasm under drought stress. Pak J Life Soc Sci 10:106-110

Jan A, Maruyama K, Todaka D, Kidokoro S, Abo M, Yoshimura E, Shinozaki K, Nakashima K, Yamaguchi-Shinozaki K (2013) OsTZF1, a CCCH-tandem zinc finger protein, confers delayed senescence and stress tolerance in rice by regulating stress-related genes. Plant Physiol 161:1202-1216

Jiang M, Zhang J (2002) Water stress-induced abscisic acid accumulation triggers the increased generation of reactive oxygen species and upregulates the activities of antioxidant enzymes in maize leaves. J Exp Bot 53:2401-2410

Kanno Y, Hanada A, Chiba Y, Ichikawa T, Nakazawa M, Matsui M, Koshiba T, Kamiya Y, Seo M (2012) Identification of an abscisic acid transporter by functional screening using the receptor complex as a sensor. Proc Nat Acad Sci 109:9653-9658

Khan SA, Chibon PY, de Vos RC, Schipper BA, Walraven E, Beekwilder J, van Dijk T, Finkers R, Visser RG, van de Weg EW, Bovy A, Cestaro A, Velasco R, Jacobsen E, Schouten HJ (2012) Genetic analysis of metabolites in apple fruits indicates an mQTL hotspot for phenolic compounds on linkage group 16. J Exp Bot 63:2895-2908

Kim H, van Oostende C, Basset GJ, Browse J (2008) The AAE14 gene encodes the Arabidopsis o-succinylbenzoyl-CoA ligase that is essential for phylloquinone synthesis and photosystem-I function. Plant J 54:272-283
Kim JI, Murphy AS, Baek D, Lee SW, Yun DJ, Bressan RA, Narasimhan ML (2011) YUCCA6 over-expression demonstrates auxin function in delaying leaf senescence in Arabidopsis thaliana. J Exp Bot 62: 3981-3992

Kosmas SA, Argyrokastritis A, Loukas MG, Eliopoulos E, Tsakas S, Kaltsikes PJ (2006) Isolation and characterization of droughtrelated trehalose 6-phosphate-synthase gene from cultivated cotton (Gossypium hirsutum L.). Planta 223:329-239

Krishnaswamy S, Verma S, Rahman MH, Kav NN (2011) Functional characterization of four APETALA2-family genes (RAP2.6, RAP2.6L, DREB19 and DREB26) in Arabidopsis. Plant Mol Biol 75:107-127

Kushiro T, Okamoto M, Nakabayashi K, Yamagishi K, Kitamura S, Asami T, Hirai N, Koshiba T, Kamiya Y, Nambara E (2004) The Arabidopsis cytochrome P450 CYP707A encodes ABA 8'-hydroxylases: key enzymes in ABA catabolism. EMBO J 23:1647-1656

Landi M (2015) Can anthocyanins be part of the metal homeostasis network in plants? Amer J Agri Biol Sci 10:170-177

Lee EJ, Matsumura Y, Soga K, Hoson T, Koizumi N (2007) Glycosyl hydrolases of cell wall are induced by sugar starvation in Arabidopsis. Plant Cell Physiol 48:405-413

Lind C, Dreyer I, López-Sanjurjo EJ, von Meyer K, Ishizaki K, Kohchi T, Lang D, Zhao Y, Kreuzer I, Al-Rasheid KA, Ronne H, Reski R, Zhu JK, Geiger D, Hedrich R (2015) Stomatal guard cells co-opted an ancient ABA-dependent desiccation survival system to regulate stomatal closure. Curr Biol 25:928-935

Matiolli CC, Tomaz JP, Duarte GT, Prado FM, Del Bem LE, Silveira AB, Gauer L, Corrêa LG, Drumond RD, Viana AJ, Di Mascio P, Meyer C, Vincentz M (2011) The Arabidopsis bZIP gene AtbZIP63 is a sensitive integrator of transient abscisic acid and glucose signals. Plant Physiol 157:692-705

Miedes E, Suslov D, Vandenbussche F, Kenobi K, Ivakov A, Van Der Straeten D, Lorences EP, Mellerowicz EJ, Verbelen JP, Vissenberg $\mathrm{K}$ (2013) Xyloglucan endotransglucosylase/hydrolase $(X T H)$ overexpression affects growth and cell wall mechanics in etiolated Arabidopsis hypocotyls. J Exp Bot 64:2481-2497

Mishra S, Kumar S, Saha B, Awasthi J, Dey M, Panda S, Sahoo L (2016) Crosstalk between salt, drought, and cold tolerance in plants: toward genetic engineering for stress tolerance. In: Tuteja N, Gill S (eds) Abiotic stress response in plants, 1 st edn. Wiley-VCH, Weinheim, pp 55-77

Orcheski B, Parker R, Brown S (2015) Pale green lethal disorder in apple (Malus) is caused by a mutation in the PHYLLO gene, which is essential for phylloquinone (vitamin $\mathrm{K}_{1}$ ) biosynthesis. Tree Genet Genomes 11:1-11

Pan X, Welti R, Wang X (2008) Simultaneous quantification of major phytohormones and related compounds in crude plant extracts by liquid chromatography-electrospray tandem mass spectrometry. Phytochem 69:1773-1781

Parrott DL, Martin JM, Fischer AM (2010) Analysis of barley (Hordeum vulgare) leaf senescence and protease gene expression: a family $\mathrm{C} 1 \mathrm{~A}$ cysteine protease is specifically induced under conditions characterized by high carbohydrate, but low to moderate nitrogen levels. New Phytol 187:313-331

Pfaffl MW (2001) A new mathematical model for relative quantification in real-time RT-PCR. Nucleic Acids Res 29:e45. doi:10.1093/nar/29.9.e45

Qu J, Kang SG, Wang W, Musier-Forsyth K, Jang JC (2014) The Arabidopsis thaliana TANDEM ZINC FINGER 1 (AtTZF1) protein in RNA binding and decay. Plant J 78:452-467

Radwan A, Hara M, Kleinwächter M, Selmar D (2014) DEHYDRIN expression in seeds and maturation drying: a paradigm change. Plant Biol 16:853-855

Reumann S (2013) Biosynthesis of vitamin $\mathrm{K}_{1}$ (phylloquinone) by plant peroxisomes and its integration into signaling molecule synthesis pathways. Subcell Biochem 69:213-229 
Robinson MD, McCarthy DJ, Smyth GK (2010) edgeR: a Bioconductor package for differential expression analysis of digital gene expression data. Bioinformatics 26:139-140

Sakuraba Y, Schelbert S, Park SY, Han SH, Lee BD, Andrès CB, Kessler F, Hörtensteiner S, Paek NC (2012) STAY-GREEN and chlorophyll catabolic enzymes interact at light-harvesting complex II for chlorophyll detoxification during leaf senescence in Arabidopsis. Plant Cell 24:507-518

Sasidharana R, Voeseneka L, Pierika R (2011) Cell wall modifying proteins mediate plant acclimatization to biotic and abiotic stresses. Crit Rev Plant Sci 30:549-559

Schippers JH, Schmidt R, Wagstaff C, Jing HC (2015) Living to die and dying to live: the survival strategy behind leaf senescence. Plant Physiol 169:914-930

Schofield RA, Bi YM, Kant S, Rothstein SJ (2009) Over-expression of STP13, a hexose transporter, improves plant growth and nitrogen use in Arabidopsis thaliana seedlings. Plant Cell Environ 32:271-285

Sherson SM, Hemmann G, Wallace G, Forbes S, Germain V, Stadler R, Bechtold N, Sauer N, Smith SM (2000) Monosaccharide/proton symporter AtSTP1 plays a major role in uptake and response of Arabidopsis seeds and seedlings to sugars. Plant J 24:849-857

Shibuya K, Ichimura K (2016) Physiology and molecular biology of flower senescence. In: Pareek S (ed) Postharvest ripening physiology of crops, 1st edn. CRC Press, Boca Raton, pp 109-125

Shimada H, Ohno R, Shibata M, Ikegami I, Onai K, Ohto MA, Takamiya $\mathrm{K}$ (2005) Inactivation and deficiency of core proteins of photosystems I and II caused by genetical phylloquinone and plastoquinone deficiency but retained lamellar structure in a T-DNA mutant of Arabidopsis. Plant J 41:627-637

Stenbaek A, Jensen PE (2010) Redox regulation of chlorophyll biosynthesis. Photochem 71:853-859

Tapia H, Young L, Fox D, Bertozzi CR, Koshland D (2015) Increasing intracellular trehalose is sufficient to confer desiccation tolerance to Saccharomyces cerevisiae. Proc Natl Acad Sci 112:6122-6127

Tehseen M, Cairns N, Sherson S, Cobbett CS (2010) Metallochaperonelike genes in Arabidopsis thaliana. Metallomics 2:556-564

Thomas H, Ougham H (2014) The stay-green trait. J Exp Bot 65:3889_ 3900

Todaka D, Shinozaki K, Yamaguchi-Shinozaki K (2015) Recent advances in the dissection of drought-stress regulatory networks and strategies for development of drought-tolerant transgenic rice plants. Front Plant Sci 6:84. doi:10.3389/fpls.2015.00084

Trapnell C, Williams BA, Pertea G, Mortazavi A, Kwan G, van Baren MJ, Salzberg SL, Wold BJ, Pachter L (2010) Transcript assembly and quantification by RNA-Seq reveals unannotated transcripts and isoform switching during cell differentiation. Nature Biotech 28: 511-515

Van Engelen FA, Hartog MV, Thomas TL, Taylor B, Sturm A, van Kammen A, de Vries SC (1993) The carrot secreted glycoprotein gene $E P 1$ is expressed in the epidermis and has sequence homology to Brassica S-locus glycoproteins. Plant J 4:855-862

Van Munster JM, Nitsche BM, Akeroyd M, Dijkhuizen L, van der Maarel MJ, Ram AF (2015) Systems approaches to predict the functions of glycoside hydrolases during the life cycle of Aspergillus niger using developmental mutants $\triangle b r l A$ and $\Delta f l b$. PLoS One 10:e116269. doi:10.1371/journal.pone.0116269
Van Oostende C, Widhalm JR, Furt F, Ducluzeau AL, Basset GJ (2011) Vitamin $\mathrm{K}_{1}$ (phylloquinone): function, enzymes, and genes. In: Rebeille F, Douce R (eds) Advances in botanical research, biosynthesis of vitamins in plants part B: vitamins B6, B8, B9, C, E, K, 1st edn. Elsevier, London, pp 230-255

Varkonyi-Gasic E, Gould N, Sandanayaka M, Sutherland P, MacDiarmid RM (2010) Characterisation of microRNAs from apple (Malus $\times$ domestica 'Royal Gala') vascular tissue and phloem sap. BMC Plant Biol 10:159. doi:10.1186/1471-2229-10-159

Velasco R, Zharkikh A, Affourtit J, Dhingra A, Cestaro A, Kalyanaraman A, Fontana P, Bhatnagar SK, Troggio M, Pruss D, Salvi S, Pindo M, Baldi P, Castelletti S, Cavaiuolo M, Coppola G, Costa F, Cova V, Dal Ri A, Goremykin V, Komjanc M, Longhi S, Magnago P, Malacarne G, Malnoy M, Micheletti D, Moretto M, Perazzolli M, Si-Ammour A, Vezzulli S, Zini E, Eldredge G, Fitzgerald LM, Gutin N, Lanchbury J, Macalma T, Mitchell JT, Reid J, Wardell B, Kodira C, Chen Z, Desany B, Niazi F, Palmer M, Koepke T, Jiwan D, Schaeffer S, Krishnan V, Wu C, Chu VT, King ST, Vick J, Tao Q, Mraz A, Stormo A, Stormo K, Bogden R, Ederle D, Stella A, Vecchietti A, Kater MM, Masiero S, Lasserre P, Lespinasse Y, Allan AC, Bus V, Chagné D, Crowhurst RN, Gleave AP, Lavezzo E, Fawcett JA, Proost S, Rouzé P, Sterck L, Toppo S, Lazzari B, Hellens RP, Durel CE, Gutin A, Bumgarner RE, Gardiner SE, Skolnick M, Egholm M, Van de Peer Y, Salamini F, Viola R (2010) The genome of the domesticated apple (Malus $\times$ domestica Borkh.). Nature Genet 42:833-839

Way RD, Lamb RC, Pratt C, Cummins JN (1976) Pale green lethal gene in apple clones. J Am Soc Hortic Sci 101:679-684

Wisniewski M, Bassett C, Norelli J, Macarisin D, Artlip T, Gasic K, Korban S (2008) Expressed sequence tag analysis of the response of apple (Malus $\times$ domestica 'Royal Gala') to low temperature and water deficit. Physiol Plant 133:298-317

Wu T, Wang Y, Zheng Y, Fei Z, Dandekar AM, Xu K, Han Z, Cheng L (2015) Suppressing sorbitol synthesis substantially alters the global expression profile of stress response genes in apple (Malus $\times$ domestica) leaves. Plant Cell Physiol 56:1748-1761

Xu YH, Liu R, Yan L, Liu ZQ, Jiang SC, Shen YY, Wang XF, Zhang DP (2012) Light-harvesting chlorophyll a/b-binding proteins are required for stomatal response to abscisic acid in Arabidopsis. J Exp Bot 63:1095-1106

Yang J, Worley E, Udvardi M (2014) A NAP-AAO3 regulatory module promotes chlorophyll degradation via ABA biosynthesis in Arabidopsis leaves. Plant Cell 26:4862-4874

Zhang D, Liu D, Lv X, Wang Y, Xun Z, Liu Z, Li F, Lu H (2014) The cysteine protease CEP1, a key executor involved in tapetal programmed cell death, regulates pollen development in Arabidopsis. Plant Cell 26:2939-2961

Zhong S, Joung JG, Zheng Y, Chen YR, Liu B, Shao Y, Xiang JZ, Fei Z, Giovannoni JJ (2011) High-throughput Illumina strand-specific RNA sequencing library preparation. Cold Spring Harb Protoc 2011:940-949

Zhou T, Yang X, Wang L, Xu J, Zhang X (2014) GhTZF1 regulates drought stress responses and delays leaf senescence by inhibiting reactive oxygen species accumulation in transgenic Arabidopsis. Plant Mol Biol 85:163-177 